\title{
Relationship between Organizational Culture and Employee Performance through Work Stress at the Regional Office of the East Java I Directorate General of Customs and Excises
}

\author{
Irsan Komar ${ }^{1}$ \\ ${ }^{1}$ Indonesian Customs Officer, Indonesia, Indonesia \\ Received: March 14, 2021 \\ Revised: April 7, 2021 \\ Accepted: April 28, 2021
}

\begin{abstract}
This study aims to analyze the Relationship between Organizational Culture and Employee Performance through Work Stress at the Regional Office of the Directorate General of Customs and Excise, East Java I. This research method is an explanatory research, the analysis unit in this study is employees who work in the Directorate General of Customs and Excise Office. East Java I region, which consists of 80 structural officials, 79 functional officials and 1323 executive staff. The method of collecting research data using a questionnaire. The results showed that organizational culture affects the work stress of employees at the Regional Office of the Directorate General of Customs and Excise, East Java I, this shows that organizational culture is able to increase the work stress of employees of the Regional Office of the Directorate General of Customs and Excise, East Java. Organizational culture influences the performance of the employees of the Regional Office of the Directorate General of Customs and Excise, East Java I, this shows that with a good and appropriate organizational culture, it is able to increase the performance of the employees of the Regional Office of the Directorate General of Customs and Excise, East Java I. New organizational culture that also improves Employee stress, namely the imposition of input into daily work activity reports by employees in the daily logbook through an internet-based application with details on the types of activities, time norms, achievement targets and employee daily problems for all levels of employees, both structural, functional and executive.
\end{abstract}

Keywords: Organizational Culture, Employee Performance, Job Stress

\section{Introduction}

Organizational culture can be the main competitive advantage instrument, namely if the organizational culture can support the organization's strategy and if it can respond to or overcome the challenges of environmental change quickly and accurately. Schein (2010) states that corporate culture or often referred to as work culture is believed by many companies to be a work culture that will have a major impact on company performance. From the opinion of Schein (2010) it can be concluded (Sobirin, 2007) that basically corporate culture has the meaning of the rules of the game in the company which will be the handle of human resources in carrying out their obligations, and values for behaving in an organization or company. the. It can also be said that corporate culture is an integrated pattern of human behavior within the organization, including thoughts, actions, conversations that are learned and taught to the next generation.

All workers must be able to properly understand the organizational culture, because this understanding is closely related to every step or activity carried out, both strategic and tactical planning and planning implementation activities, where each activity must be based on the organizational culture. Culture is closely related to how employees perceive the characteristics of organizational culture (Robin, 2014), and culture can produce effects that greatly affect 
individuals and performance, especially in a competitive environment, this influence can even be greater than strategy, structure. organization, management systems, values of financial analysis, leadership and others.

Stress is a condition of tension that affects one's emotions, thought processes and condition (Handoko, 2016). In this condition, work stress arises among employees and worries about their safety at work and their families, especially for employees who work far from their families. Meanwhile, performance emphasizes understanding as a result or what comes out (outcomes) from a job and their contribution to the organization. Amins, (2009) states that a person's performance is a combination of abilities, efforts and opportunities that can be had from the results of his work. Performance is defined by Nawawi (2018) as an activity to improve the quality or quality of work of an employee who will later determine the assessment of a position for a personnel. Based on this definition, it is very clear that performance indicates the quality or quality of employee work and is used as the basis for granting positions. Employees who have high performance will be given a higher position (promotion) and vice versa, employees with low performance are likely to be demoted (demotion) or transferred to another department (transfer). Based on this description, this study analyzes the Relationship between Organizational Culture and Employee Performance through work stress.

\section{Methods}

This research is an explanatory research which will prove the causal relationship between the independent variables. The unit of analysis in this study is employees who work in the Directorate General of Customs and Excise of the East Java I Regional Office consisting of 80 structural officials, 79 functional officials and 1323 people as executing employees. Primary and secondary data were collected by means of cross section, namely research at a certain time using many respondents. The research data were collected directly to the research location. The research data collection method used a questionnaire, namely the method of collecting data by giving a number of written statements to the respondents who were then asked to fill them out.

This organizational culture variable is operationally measured using six indicators adopted and adjusted from (Robbins, 2008; Schein, 2010), namely; (1) Innovate and take risks; (2) Attention and details; (3) Result orientation; (4) Team orientation; (5) Aggressiveness. This employee work stress variable is operationally measured using five indicators developed by Robbins (2008), Allen (1996), namely; (1) Demands duties; (2) Role demands; (3) Interpersonal demands; (4) Organizational structure; (5) Organizational leadership. This performance variable is operationally measured using three indicators developed by Robbins (2008) (1) Quality of work; (2) Quantity of work; (3) Punctuality of time (4) Effectiveness

\section{Result and Discussion}

Organizational culture is a pattern / system in the form of attitudes, values, behavioral norms, language, beliefs, rituals that are formed, developed and passed on to members of the organization as the personality of the organization that differentiates it from other organizations and determines how the group feels, thinks and reacts to diverse environments and serves to address internal and external adaptation problems. The organizational culture variable is measured using six indicators, namely: innovation and taking risks, attention and details, result orientation, team orientation, aggressiveness, and stability.

Table 1. Descriptive Analysis of Organizational Culture Variables

\begin{tabular}{|l|c|c|}
\hline \multicolumn{1}{|c|}{ Budaya organisasi } & Mean Indicator & Description \\
\hline Innovate and take risks & 4.104 & Strong \\
\hline Attention and details & 3.976 & Strong \\
\hline
\end{tabular}

Copyright @ 2021, Journal of Asian Multicultural Research for Economy and Management Study, Under the license CC BY-SA 4.0 


\begin{tabular}{|l|l|l|}
\hline Result orientation & 3.941 & Strong \\
\hline Team orientation & 3.897 & Strong \\
\hline Aggressiveness & 3.949 & Strong \\
\hline and Stability & 3.705 & Strong \\
\hline Mean organizational culture & 3.928 & Strong \\
\hline
\end{tabular}

Source: The results of descriptive testing of processed data (attachment 6)

The results of descriptive calculations get an average score of organizational culture of 3,928, this acquisition on an answer scale of 1 to 5 is a score between 3.41-4.20. These results explain that the average employee who is the respondent in this study states that the organizational culture in the regional office environment of the Directorate General of Customs and Excise Jawa I is strong, and still has the potential to be improved to be very strong.

\section{Job Stress}

Job stress is a stressful condition that affects a person's thought processes, emotions, and conditions, as a result, too much stress can threaten a person's ability to deal with the environment and ultimately interfere with the performance of one's duties. Employee work stress variables are measured using 5 (five) indicators, namely: task demands, role demands, interpersonal demands, organizational structure, and organizational leadership.

Table 2. Analysis of Job Stress Variable Descriptions

\begin{tabular}{|c|l|c|c|}
\hline No & Work Stress & Mean Indicator & Description \\
\hline 1 & Duty demands & 3.887 & Strong \\
\hline 2 & Role demands & 3.795 & Strong \\
\hline 3 & Interpersonal demands & 3.875 & Strong \\
\hline 4 & Organizational structure & 3.963 & Strong \\
\hline 5 & Organizational leadership & 3.802 & Strong \\
\hline & Mean Job Stress & 3.864 & Tinggi \\
\hline
\end{tabular}

Source: The results of descriptive testing of processed data (attachment 6)

The results of descriptive calculations get an average score of work stress of 3,864, this acquisition on an answer scale of 1 to 5 approaches the value of 4 which is a high score. These results explain that the average employee who is the respondent in this study says that work stress in the Regional Office of the Directorate General of Customs and Excise, East Java I is high.

\section{Employee Performance}

Employee performance is a record of the results obtained from certain job functions or certain activities during a certain period of time. Performance variables are measured using four indicators, namely: Quality of work results, Quantity of work results, Timeliness, and Effectiveness.

Table 3. Analysis of Employee Performance Variable Descriptions

\begin{tabular}{|c|l|c|c|}
\hline No & \multicolumn{1}{|c|}{ Employee performance } & Mean & Description \\
\hline 1 & The quality of the work & 3.757 & High \\
\hline 2 & Quantity of work & 3.892 & High \\
\hline 3 & Punctuality & 3.793 & High \\
\hline 4 & Effectiveness & 3.873 & High \\
\hline
\end{tabular}

Copyright (C 2021, Journal of Asian Multicultural Research for Economy and Management Study, 


\begin{tabular}{|l|l|l|}
\hline Mean employee performance & 3.828 & High \\
\hline
\end{tabular}

Source: The results of descriptive testing of processed data (attachment 6).

The results of descriptive calculations get an average score of employee performance of 3,828, this acquisition on an answer scale of 1 to 5 is a score between $3.41-4.20$. These results explain that the average employee who is the respondent in this study states that the performance of employees in the Regional Office of the Directorate General of Customs and Excise, East Java I is high.

\section{Organizational Culture Variables}

The indicators of organizational culture variables consist of: innovation and taking risks, attention and details, result orientation, team orientation, aggressiveness, and stability.

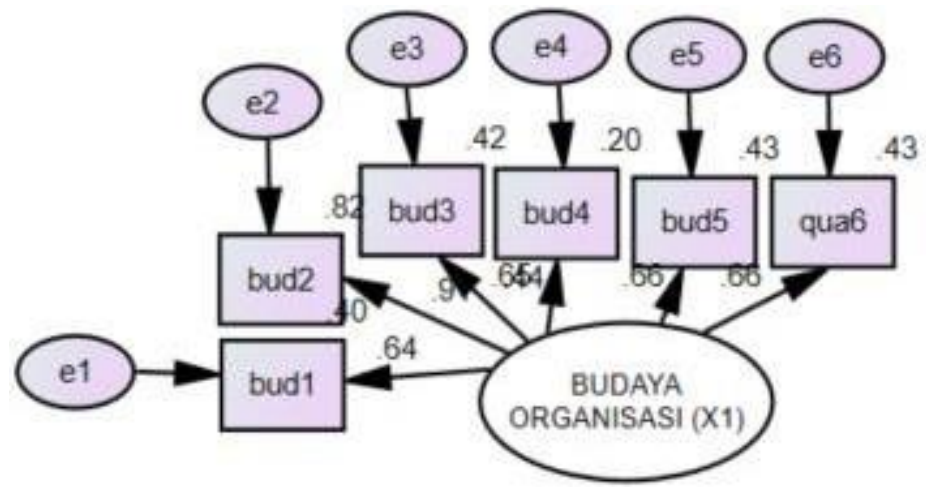

Figure 1. Variable Diagram of Organizational Culture

Source: Variable Loading Factors (Appendix 7)

Analysis using factor analysis to look for factors forming organizational culture variables, it can be seen that the dominant factors that shape organizational culture are Attention and details (0.908), Aggressiveness (0.659), Stability (0.656), Result Orientation (0, 651), Innovation and taking risks (0.631), and team orientation (0.443) as shown in Figure 5.4.

Based on the results of statistical tests in AMOS version 24, the value of the CR (crical ratio) for each indicator forming the organizational culture variable is greater than 2 (Jöreskog \& Sörbom, 1982). Thus, the five indicators are indicators that significantly shape organizational culture.

Table 4. Loading Factors of Organizational Culture

\begin{tabular}{|c|c|c|c|c|c|c|}
\hline \multicolumn{2}{|c|}{ Regression Weights } & \multirow{2}{*}{$\begin{array}{c}\text { Estimate } \\
0,748\end{array}$} & \multirow{2}{*}{$\begin{array}{c}\begin{array}{c}\text { Standart } \\
\text { Estimate }(\lambda)\end{array} \\
0,659\end{array}$} & \multirow{2}{*}{$\begin{array}{l}\text { S.E. } \\
0,085\end{array}$} & \multirow{2}{*}{$\begin{array}{l}\text { C.R. } \\
8.850\end{array}$} & \multirow{2}{*}{\begin{tabular}{c|}
$\mathbf{P}$ \\
0,000
\end{tabular}} \\
\hline zbud5 & $\longleftarrow$ BUD & & & & & \\
\hline qua6 & $4-$ BUD & 0,905 & 0,656 & 0,105 & 8.623 & 0,000 \\
\hline bud1 & $\longleftarrow$ BUD & 1,000 & 0,635 & 0,000 & 2.000 & 0,000 \\
\hline bud3 & \begin{tabular}{l|l}
$\leftarrow$ & BUD \\
\end{tabular} & 1,165 & 0,651 & 0,136 & 8.568 & 0,000 \\
\hline bud4 & $4-$ BUD & 0,680 & 0,443 & 0,106 & 6.416 & 0,000 \\
\hline bud2 & $\longleftarrow$ BUD & 1,333 & 0,908 & 0,118 & 11.313 & 0,000 \\
\hline
\end{tabular}

Table 5.15, shows that the biggest contribution in shaping organizational culture is an indicator of attention and detail, meaning that respondents prioritize attention and details in terms of organizational culture which shows that management values every decision made by employees in carrying out their duties, and also that management encourages employees to be brave in making decisions about their duties. The next dominant indicator is aggressiveness,

Copyright ( $)$ 2021, Journal of Asian Multicultural Research for Economy and Management Study, Under the license CC BY-SA 4.0 
which means that the leader encourages each employee to achieve optimal work results, and also the leader is always active in monitoring the level of employee productivity. This is followed by the Stability indicator, which means that the person in charge is based more on seniority than on work performance, and that each organizational activity is more aimed at achieving positive growth. The next dominant indicator is result orientation, which means that employees do every job carefully, and also in every job, employees report it in detail. The next indicator is innovation and taking risks, this shows that management is obliged to emphasize employees to make positive changes in their work, and employees work creatively without waiting for management support. The last one is a team orientation which shows that the leader always forms a work team in carrying out a particular task, and also the leadership of encouraging the completion of a task through teamwork, compared to individual work.

\section{Employee Performance Variables}

Indicators of employee performance variables consist of: quality of work results, quantity of work results, timeliness, and effectiveness. By using factor analysis to look for factors forming employee performance variables, it can be seen that the dominant factors that make up employee performance are effectiveness (0.847), followed by quality of work results $(0.839)$, timeliness (0.776), and quantity of work results (0.552). as shown in the image below:

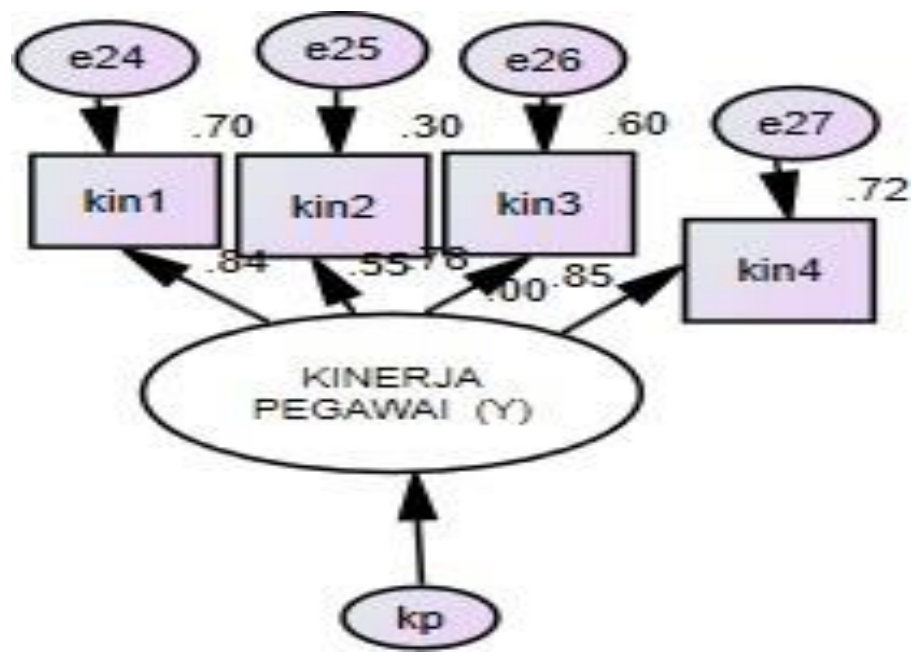

Figure 2. Employee Performance Variable Diagram

\section{Source: Variable Loading Factors (Appendix 7)}

Based on the results of statistical tests in AMOS version 24, the value of the CR (crical ratio) for each indicator forming the Employee Performance variable is greater than 2 Jöreskog \& Sörbom, (1982). thus, the four indicators are indicators that significantly shape employee performance. The biggest contribution in shaping Employee Performance is an indicator of effectiveness, which means that employees complete every job task with the minimum time possible, and also that employees complete every job task that is assigned to employees quickly. The next dominant indicator is the quality of work results, which means that employees are able to complete each given task, in accordance with the quality standards set by the organization, and also the quality of the work of employees according to the quality set by the organization. The next indicator that forms employee performance variables is accuracy. time which means that the attendance of employees is in accordance with the working hours set by the organization, and each employee completes each job task on time. The last indicator is that the organization provides training in prevention and management of possible hazards, and also when working, employees feel that they are not worried about accidents because the security tools or facilities are complete. The dominant indicator of the occurrence of Employee 
Performance variables is a safe work environment, which means that the atmosphere in the workplace makes employees feel comfortable, and also that employees are not easily dismissed from work by the company because they have a clear work contract.

Table 5. Employee Performance Loading Factors

\begin{tabular}{|c|c|c|c|c|c|c|}
\hline \multicolumn{2}{|c|}{ Regression Weights } & Estimate & $\begin{array}{l}\text { Standart } \\
\text { Estimate }(\lambda)\end{array}$ & S.E. & C.R. & $\mathbf{P}$ \\
\hline kin3 & $\longleftarrow \quad$ KIN & 0,971 & 0,776 & 0,073 & 13,253 & 0,000 \\
\hline kin2 & $\longleftarrow$ KIN & 0,768 & 0,552 & 0,087 & 8,837 & 0,000 \\
\hline kin 1 & $\longleftarrow$ KIN & 1,000 & 0,839 & 0,000 & 2,000 & 0,000 \\
\hline kin4 & $\longleftarrow$ KIN & 1,208 & 0,847 & 0,081 & 14,834 & 0,000 \\
\hline
\end{tabular}

Source: Variable loading factor (appendix 7)

Followed by career development indicators, which means that the organization has a policy or job rotation program for employees, and also the organization has a clear career path program for employees. The last indicator is the quantity of work results which shows that employees are able to complete each task assigned to them according to the targets set by the organization, and also employees are able to complete each task assigned to them that exceeds the targets set by the organization. As shown in table 5.20.

\section{Variable Job Stress}

Indicators of work stress variables consist of: task demands, role demands, interpersonal demands, organizational structure, and organizational leadership. By using factor analysis to look for the factors forming the job stress variable, it can be seen that the dominant factors that make up job stress are interpersonal demands (0.753), followed by task demands (0.598), organizational structure (0.540), role demands (0.540), and organizational leadership (0.341), as shown in the image below:

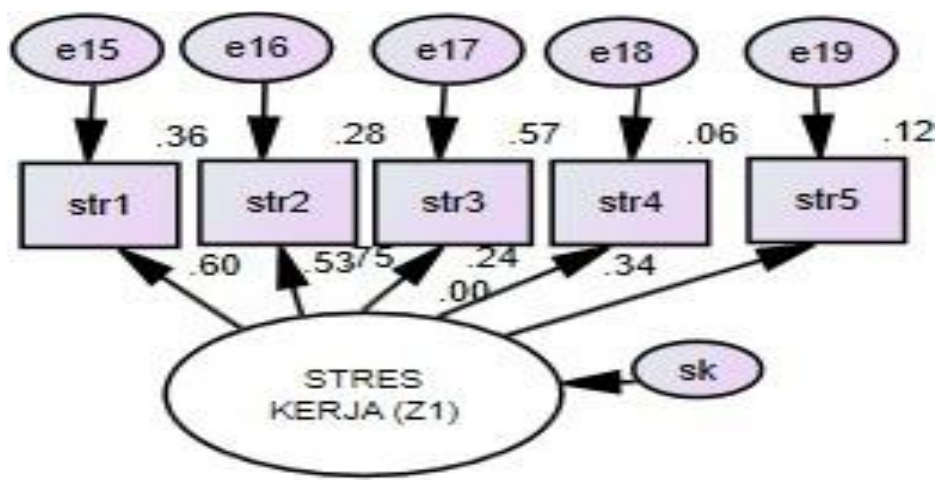

Figure 3. Variable Diagram of Work Stress

Source: Variable Loading Factors (Appendix 7)

Based on the results of statistical tests in AMOS version 24, the value of the CR (crical ratio) for each indicator forming the work stress variable is greater than 2 Jöreskog \& Sörbom, (1982), thus, these four indicators are significant indicators. forming job stress. The biggest contribution in forming job stress is an indicator of interpersonal demands, meaning that respondents prioritize work stress in terms of interpersonal demands, namely the existence of relationships between employees that go well, and employees get social support from coworkers. The next indicator is the demands of the job, this shows that respondents feel the work is too much, and the company demands more than the ability of employees without adequate facilities. The next indicator is the organizational structure that the regulations applied

Copyright ( $)$ 2021, Journal of Asian Multicultural Research for Economy and Management Study, 
by the organization make it difficult for employees to work, and also the regulations applied by the organization that are difficult for employees to follow. The next indicator is the role demands, which means that employees at work are always pressed for time to complete their work well, and also the task demands are too high, so that it becomes burdensome for the tasks of my employees. The last indicator is organizational leadership, this shows that the leader has a good relationship with subordinates, and also the leader can create a conducive work atmosphere. The leader can create a conducive work atmosphere. As shown in the table below:

Table 6. Loading Factor Job Stress

\begin{tabular}{|c|l|l|c|c|c|l|c|}
\hline \multicolumn{2}{|l|}{ Regression Weights } & Estimate & $\begin{array}{l}\text { Standart } \\
\text { Estimate }(\lambda)\end{array}$ & S.E. & C.R. & P \\
\hline str1 & - & STR & 1,000 & 0,598 & 0,000 & 2,000 & 0,000 \\
\hline str2 & - & STR & 0,985 & 0,529 & 0,171 & 5,752 & 0,000 \\
\hline str3 & - & STR & 1,587 & 0,753 & 0,236 & 6,729 & 0,000 \\
\hline str4 & - & STR & 0,539 & 0,540 & 0,177 & 3,050 & 0,000 \\
\hline str5 & - & STR & 0,831 & 0,341 & 0,203 & 4,083 & 0,000 \\
\hline
\end{tabular}

Source: Variable loading factor (appendix 7)

Organizational culture has a significant effect on the work stress of employees at the Regional Office of the Directorate General of Customs and Excise, East Java I.

The path coefficient of the organizational culture variable on the work stress of the employees of the Regional Office of the Directorate General of Customs and Excise, East Java I is 0.668 with a critical ratio (CR) of 5.860 and a probability value of 0.000 . The probability value is smaller than 0.05 , this indicates that the influence of organizational culture variables on the work stress of employees of the Regional Office of the Directorate General of Customs and Excise, East Java I is significant or reliable. While the positive value of beta explains the effect is unidirectional, meaning that the organizational culture of East Java I Customs and Excise employees contributes to an increase in work stress, and vice versa, failure to form an organizational culture can reduce employee work stress. The contribution made in this contribution amounted to $66.8 \%$.

In the descriptive description it is known that, the organizational culture of the employees of Customs and Excise of East Java I reached a strong level (mean value $=3,928$ in the scale range 1 to 5). In addition to showing this level, it is not optimal, but in another sense it shows the possibility of increasing employee work stress through organizational culture. By using factor analysis, it is known that the dominant indicators that shape organizational culture are attention and detail indicators, followed by indicators of aggressiveness, stability, result orientation, innovation and risk taking, and team orientation. This shows that East Java I Customs and Excise employees prioritize attention and details, then think about aggressiveness, stability, result orientation, innovation and taking risks, and team orientation.

With the dominance of attention and detail indicators, followed by indicators of aggressiveness, stability, result orientation, innovation and risk taking, and team orientation, on this organizational culture variable, the leadership of the Regional Office of the Directorate General of Customs and Excise, East Java I, should pay more attention. and these details, because the attention and detail is that the leadership of the organization respects every decision made by employees in carrying out their duties, and the leadership of the organization encourages employees to be courageous in making decisions about their duties. Likewise with the aggressiveness indicator, which in this study is the second dominant indicator, therefore the leadership of the Regional Office of the Directorate General of Customs and Excise, East Java 
I as far as possible gives more attention to employee aggressiveness, because aggressiveness is that the leadership encourages each employee to be able to. achieve optimal work results, and leaders are always active in monitoring employee productivity levels. Likewise with the stability indicator, because stability is that the person in charge is based more on seniority than on work performance, and each organizational activity is more aimed at achieving positive growth. The next indicator is result orientation, which means that employees do every job carefully, and in every job, employees report it in detail. The next indicator is team orientation which means that the leadership always forms a work team in carrying out a particular task, and the leadership encourages the completion of a task through team work, compared to the work of individual employees at the Regional Office of the Directorate General of Customs and Excise, East Java I.

With the ongoing reforms at the Regional Office of DJBC Jatim I, the organizational culture has also undergone significant changes. This is reflected in the change in the daily culture in the office that previously did not exist into a routine activity that must be carried out. For example, every morning during office hours each work unit in the group in the work room or field conducts "standing" activities, namely praying together, pronouncing basic employee attitudes and sharing information among employees related to work problems and other issues. offices that are considered important for 15 minutes. This activity is quite inconvenient and stressful for employees because at least 2 minutes before office hours, each employee must be in the room or workplace to gather with his group colleagues and the absence of employees for this activity is used as an element of disciplinary assessment by superiors by implementing an attendance list. this activity. In addition, every employee must memorize the basic employee attitude items that are long enough to be pronounced in turns. Another example of a new organizational culture that also increases employee stress is the imposition of inputting daily work activity reports into daily logbooks through an internet-based application with details on types of activities, time norms, achievement targets and employee daily problems for all levels of employees, both structural and functional. and executor. This is used as the basis for daily reporting to the leadership and is used as one of the bases for employee performance appraisals. The stress that arises from this is because the daily work activities that are already busy with big responsibilities are again preoccupied with the obligation to fill in this logbook, which if not done will result in reduced evaluation from superiors. Another organizational culture that contributed to employee stress during this pandemic, namely the obligation to wear a mask every time they enter the office until returning home, wash their hands before entering the room, go through the disinfectant booth, limit the number of employees who enter the room to maintain their distance, and more importantly maintain safety. yourself from several friends who are indicated to have had the plague, either sick or without symptoms.

The results of this study are appropriate and can confirm previous research conducted by Kokt \& Ramarumo (2015) on organizational culture variables which prove that organizational culture has an effect on work stress. Similar to the research results of Amilia \& Nugrohoseno (2018) which prove that organizational culture has a significant positive effect on job satisfaction and employee job stress. It is different and cannot confirm the research conducted by Pamungkas, (2016), which proves that organizational culture has no significant effect on employee performance. Organizational culture has a significant effect on employee work stress. The results of this study are also different from the results of research conducted by Sihotang (2015), which shows that there is a negative influence of organizational culture on work stress.

Organizational culture has a significant effect on the performance of the employees of the Regional Office of the Directorate General of Customs and Excise, East Java I 
The path coefficient of the organizational culture variable on the performance of the employees of the Regional Office of the Directorate General of Customs and Excise, East Java I is 0.664 with a critical ratio (CR) of 12.736 and a probability value of 0.000 . The probability value is smaller than 0.05 , this indicates that the influence of organizational culture variables on the performance of the employees of the Regional Office of the Directorate General of Customs and Excise, East Java I is significant or reliable. While the positive value of beta explains that the effect is unidirectional, meaning that the organizational culture of East Java I Customs and Excise employees contributes to improving employee performance, and vice versa failure to form an organizational culture can reduce the performance of employees at the Regional Office of the Directorate General of Customs and Excise, East Java I. given in the contribution amounted to $66.4 \%$.

Descriptive description shows that, the organizational culture of Customs and Excise employees in East Java I reached a strong level with an average value of $=3,928$. From the factor analysis, it is known that the dominant factors that make up organizational culture are attention and detail indicators, followed by indicators of aggressiveness, stability, result orientation, innovation and risk taking, and team orientation. This shows that East Java I Customs and Excise employees prioritize attention and details, then think about aggressiveness, stability, result orientation, innovation and taking risks, and team orientation.

The dominance of attention and detail indicators, followed by indicators of aggressiveness, stability, result orientation, innovation and risk taking, and team orientation, on this organizational culture variable, the leadership of the Regional Office of the Directorate General of Customs and Excise, East Java I, should pay more attention and attention. These details, because of the attention and details, are that organizational leaders respect every decision made by employees in carrying out their duties, and organizational leaders encourage employees to be courageous in making decisions about their duties. Likewise with the aggressiveness indicator, which in this study is the second dominant indicator, therefore the leadership of the Regional Office of the Directorate General of Customs and Excise, East Java I as far as possible gives more attention to employee aggressiveness, because aggressiveness is that the leadership encourages each employee to be able to. achieve optimal work results, and leaders are always active in monitoring employee productivity levels. Likewise with the stability indicator, because stability is that the person in charge is based more on seniority than on work performance, and each organizational activity is more aimed at achieving positive growth. The next indicator is result orientation, which means that employees do every job carefully, and in every job, employees report it in detail. The next indicator is team orientation, which means that the leadership always forms a work team in carrying out a particular task, and the leadership encourages the completion of a task through teamwork, compared to the work of individual employees at the Regional Office of the Directorate General of Customs and Excise, East Java I.

The reality that we can find about this, namely the culture of daily reporting of employees to superiors through daily logbooks makes it easier for the head of the office to know the daily performance of employees and the problems that occur so that they can quickly find a way out of a problem that occurs which will prevent the problem from getting bigger. The culture of "standing" also allows superiors and colleagues to provide input to each other on work problems that each employee may face.

The results of this study are appropriate and can confirm previous research conducted by Harwiki (2013), regarding organizational culture variables which state that organizational culture has a significant effect on employee performance. It is different and cannot confirm the 
results of Pamungkas' research, (2016) which proves that organizational culture has no effect on employee performance, while organizational culture has an effect on work stress.

\section{Conclusion}

Organizational culture affects the work stress of employees at the Regional Office of the Directorate General of Customs and Excise, East Java I, this shows that organizational culture is able to increase the work stress of employees of the Regional Office of the Directorate General of Customs and Excise, East Java. Organizational culture affects the performance of the employees of the Regional Office of the Directorate General of Customs and Excise, East Java I, this shows that with a good and appropriate organizational culture, it is able to increase the performance of the employees of the Regional Office of the Directorate General of Customs and Excise, East Java I.

\section{References}

Allen, M. W. (1996). The relationship between communication, affect, job alternatives, and voluntary turnover intentions. Southern Journal of Communication, 61(3), 198-209.

Amilia, S. P. N., \& Nugrohoseno, D. (2018). Pengaruh budaya organisasi dan stres kerja terhadap kepuasan kerja karyawan pada PT. Kereta Api Indonesia Persero Daop 8 Surabaya. BISMA (Bisnis dan Manajemen), 7(1), 26-33.

Amins, A. (2009). Manajemen kinerja pemerintah daerah. LaksBang Pressindo.

Handoko, T. H. (2016). Manajemen personalia dan sumberdaya manusia. BPFE. Available from: http://repository.pelitabangsa.ac.id/xmlui/handle/123456789/1734

Harwiki, W. (2013). Pengaruh Servant Leadership Terhadap Motivasi, Budaya Organisasi, Komitmen Organisasional, Keterlibatan Pekerjaan, Organizational Citizenship Behavior, Dan Kinerja Karyawan (Studi Pada Unit Usaha Kope (Doctoral dissertation, Universitas Brawijaya).

Jöreskog, K. G., \& Sörbom, D. (1982). Recent developments in structural equation modeling. Journal of marketing research, 19(4), 404-416.

Kokt, D., \& Ramarumo, R. (2015). Impact of organisational culture on job stress and burnout in graded accommodation establishments in the Free State province, South Africa. International Journal of Contemporary Hospitality Management.

Nawawi, H. H. (2018). Manajemen Sumber Daya Manusia untuk bisnis yang kompetitif. Yogyakarta: Gajah Mada University.

Pamungkas, D. G. (2016). Pengaruh Budaya Organisasi, Karakteristik Kerja, dan Stres Kerja, Serta Dampaknya Pada Kinerja Pegawai (Studi Pada PT. PLN (Persero) AP2B Sistem Minahasa. Jurnal Riset Bisnis dan Manajemen, 4(3).

Robbins, S. P., \& Judge, T. A. (2008). Perilaku organisasi edisi ke-12. Jakarta: Salemba Empat, 11.

Schein, E. H. (2010). Organizational culture and leadership (Vol. 2). John Wiley \& Sons.

Sobirin, A. (2007). Budaya Organisasi: Pengertian, makna dan aplikasinya dalam kehidupan organisasi. Yogyakarta: UPP, STIM YKPN. 